mental defectives by the local authority, the admittance to colonies, the community care and ' supervision, must be considered as a measure of real mental hygiene.

Reading in the last annual report of the Board of Control the chapter about mental deficiency, I was astonished at the development which has taken place in colony nursing, as well as in community care, but especially it struck me that in spite of the now prevailing economical difficulties, there was a firm desire to arrive at further developments in accordance with the scheme of the law. I sincerely hope that those who occupy themselves with this work-and I say this especially with a view to your own work, Mr. President-will come nearer to the ideal they aim at. With respect to scientific and social work there are fortunately no barriers, and others will, no doubt, profit by that which you have attained.

During the last few years, Mr. President, we, in Holland, have experienced great interest in your work with respect to the manner of nursing in our mental hospitals. The more active treatment of the mentally ill has evidently attracted several among you. It was a great honour to us to be visited this year by the Chairman and several Commissioners of the Board of Control. The interest shown by the representatives of this important body and by other visitors was a great satisfaction to us. It fortifies our expectation, that the methods that are being applied with us will influence vour institutions, and as is the case with us, will contribute to the improvement of the position of the patients. I need not say that any of you who would like still to come over to my country can be sure that we will receive you with the greatest pleasure.

Permit me also, on behalf of the Dutch Association for Psychiatry and Neurology, to present to your Association our best wishes for its further life, and to express the hope that the excellent relations between our Associations will continue, certainly to the end of our days. (Applause.)

The Presinent expressed his gratitude and that of Mrs. Turner to members for the very kind vote, and thanked Dr. Pameijer, on behalf of the Association for his kind remarks.

In the afternoon members were entertained by the President to a motor coach drive to Felixstowe, where tea was provided, and to the Constable country.

\title{
SCOTTISH DIVISION.
}

A MeEtixg of the Scottish Division of the Royal Medico-Psychological Association was held at Roxburgh District Mental Hospital, Melrcse, on Friday, June 2, 1933.

There were present: Drs. Douglas McRae, J. H. Macdonald, W. D. Chambers, C. J. Shaw, T. F. Rodger, D. C. Dewar, Thos. Dymock, P. Steele, Donald Ross, W. M. Ogilvie, Neil T. Kerr, J. H. C. Orr, W. M. Ford Robertson, R. Mary Barclay, R. B. Campbell, H. C. Marr, T. C. Mackenzie, Reginald Bailey, Thos. Junor and W. M. Buchanan.

Dr. J. H. Macdonald, Divisional Chairman, presided.

The minutes of the previous meeting were read, approved and signed by the Chairman.

Apologies for absence were intimated from the President-Elect, Drs. Dunlop Robertson, C. A. Crichlow, Angus Macniven, Constance Hunter, Alex. Dick, W. Boyd, A. Ninian Bruce, D. J. Forbes, Ronald Stewart, R. D. Hotchkis, C. C. Easterbrook, Dods Brown and Sir Arthur Rose.

Drs. C. J. Shaw and C. G. A. Chislett were unanimously elected Representative Members of Council for the year 1933-1934, and Dr. Wm. M. Buchanan was unanimously elected Divisional Secretary.

Dr. C. J. Shaw was unanimously elected Chairman of the Division.

The following were unanimously nominated as members of the Mental Nursing Advisory Committee to the General Nursing Council for Scotland : Drs. Douglas Mc Rae, T. C. Mackenzie, R. D. Hotchkis, Donald Ross and Win. M. Buchanan. The Divisional Committee of Management was appointed, consisting of the Nominated Member of Council, the two Representative Members of Council, the Divisional Secretary and Dr. T. R. C. Spence.

The following candidates, after ballot, were unanimously admitted ordinary members of the Association :

George James Irvine Linklater, O.B.E., M.D., M.R.C.P.E., D.P.H., D.T.M., Assistant Medical Officer of Health, Edinburgh; I6, Dudley Avenue, Leith. Proposed by Drs. H. Ferguson Watson, C. D. Bruce and Wm. M. Buchanan.

James Joh: Mitchell, M.B., Ch.B.Glas., F.R.I.P.H., Medical Officer, Uganda Medical Service; I 4 , Norse Road, Scotstoun, Glasgow.

Proposid by Drs. Angus Macniven, Aidan Thomson and Wm. M. Buchanan.

Dr. MARR reminded members that at the approaching Honorary Graduation Ceremony at Edinburgh University Sir Arthur Rose, Chairman of the General Board of Control, would receive 
the degree of LI..D., and suggested that the occasion afforded an opportunity for the Division to show its appreciation of Sir Arthur's services by presenting him with robes for the ceremony. The suggestion was enthusiastically accepted, and the Secretary was instructed to make the necessary arrangements.

Dr. Steele and his assistants conducted members over the hospital.

Members were kindly entertained to lunch in the hospital, after which Provost FisHER, on behalf of the Joint Committee, welcomed members to Melrose; and the CHaIRMax thanked the Joint Committee and Dr. Steele and his staff for their kind hospitality, and for the arrangements made in connection with the meeting.

After lunch members were kindly taken a motor drive through Bowden, .Newtown St. Boswells, Drvburgh and Bemersyde, returning to Melrose by Newstead.

Dr. and Mrs. Steele kindly entertained members to tea.

\section{IRISH DIVISION.}

Tue Simmer Quarterly aNd Clinical MeEting of the Irish Division was held at the Donegal District Mental Hospital, Letterkenny, by the kind invitation of Dr. J. C. Martin, on Thursday, July 13,1933 .

There were present the following members: Dr. L. Gavin, in the Chair; Drs. S. Blake, R. D. Brennan, P. J. Cassin, P. J. Courtney, J. O'C. Donelan, J. Dunne, Nora May FitzGerald, John FitzGerald, D. L. Kelly, B. Lyons, R. R. Leeper, Elizabeth Mahony, J. C. Martin, P. Moran, J. C. Osburne, Eveleen $O^{\prime} B r i e n, F . O^{\prime} C$. Walsh and R. Thompson (Hon. Sec.), and the following visitors: Drs. J. P. McGinley, P. McGarvey, Annie J. Dunlevy, Catherine M. O'Brien and Mr. J. V. Callaghan, L.D.S.

In the forenoon members were conducted over the Hospital, and noted with interest the many beautiful examples of needlework done by the female patients. Later, members and visitors were entertained to luncheon.

The minutes of the previous meeting were read, approved and signed by the Chairman.

The report of the sub-committee appointed to inquire into the question of a central pathological laboratory and other matters was read by Dr. Moras.

Dr. DoNelan strongly supported the recommendations of the sub-committee for a central patholoyical laboratory, and stressed the urgent need which existed for such a laboratory, which should be an Irish centre of research into the problems of mental disease.

Dr. DiNe, Dr. Kelly, Dr. Martin, Dr. LeEPER and Dr. Moran also spoke in favour of the sub-committee's recommendations. Dr. KELlY urged that the Director should be a whole-time officer, and Dr. LEEPER insisted that the research conducted should be primarily. in to the problems presented by mental disease.

Dr. O'Briex, Asst. M.O.H., co. Donegal, pointed out the need she had found for the proper investigation and treatment of mental defect, especially that associated with epilepsy, and she suggested that research into these problems might be carried out in the contemplated laboratory.

Finally, on the motion of Dr. KELLY, seconded by Dr. CAssin, the sub-committee's report-with some minor emendations-was unanimously adopted. The sub-committee was further instructed to prepare a detailed scheme for the establishment of such a laboratory, and to submit it to the proper authorities.

Arising out of Dr. O'Brien's remarks, a discussion took place on the question of the provision of suitable accommodation for mental defectives.

Dr. Gavin and Dr. Dovelan stressed the undesirability of admitting youthful defectives to the District Mental Hospitals.

Dr. LEEPER referred to the excellent results he had recently seen in the training of defectives at Colchester.

It was finally decided-on the motion of Dr. Morax-that the medical superintendents of the district mental hospitals be asked to furnish particulars of the numbers of defectives in these institutions for whom more suitable accommodation should be found elsewhere.

The SECRETARY suggested that it would be desirable to accept nominations for the posts of Divisional Secretary and Representative Members of Council at the November meeting of the Division, in open meeting, as had been the practice for some time in another Division.

This was agreed to.

Dr. LEEPER reported that a badge would shortly be available for the use of the Chairman of the Division.

The Autumn Meeting of the Division was fixed for Thursday, November 2, 1933, at the Royal College of Physicians, Dublin. 